\title{
MANUFACTURING AND CHARACTERIZATION OF ACTIVATED CARBON FROM BIOSOLIDS FOR TREATMENT OF WASTEAWATER
}

\author{
Hossam Altaher ${ }^{1}$ and Tarek E. Khalil ${ }^{1,2}$ \\ 1 Department of Chemical Engineering Technology, Yanbu Industrial College P.O. Box 30436, Saudi Arabia \\ 2 Chemistry Department, Faculty of Science, Alexandria University P.O. Box 426 Ibrahimia, Alexandria 21321, Egypt \\ haltaher@hotmail.com (or haltaher@vt.edu)
}

\begin{abstract}
This paper deals with the manufacturing of activated carbon from locally available agricultural waste, namely dates stones (DS) to be used as cheap adsorbent for wastewater treatment. The manufacturing process includes the use of zinc chloride, phosphoric acid and sulfuric acid as chemical activators. The temperature and time of activation were varied to produce activated carbons with different properties. The adsorption of methylene blue $(\mathrm{MB})$ on the produced activated carbon was investigated. The date stones, charcoal and the activated carbon samples were characterized using Fourier Transform Infrared spectroscopy and scanning electron microscope techniques. The results indicated that all the produced activated carbons have good adsorptivity towards methylene blue. The phosphoric acid was found to be the best activator when combined with carbonization temperature of $400{ }^{\circ} \mathrm{C}$ for one hour. All the prepared samples were found to have micro pores with that prepared using sulfuric acid to irregular compared to the other two types. The surface of the prepared samples was found to contain many functional groups was $\mathrm{C}-\mathrm{O}$ to be predominant.
\end{abstract}

Keywords: Activated Carbon, Adsorption, Wastewater, Date Stones, Methylene Blue, Characterization

\section{INTRODUCTION}

Saudi Arabia has many heavy and light industries. Most of these produce wastewater effluents. Every day Red Sea receives thousands of cubic meters of wastewater containing; even after treatment of such wastewater, high concentrations of different pollutants. It is very urgent to search for a cheap and efficient method to treat these pollutants. Industry has an important role in our life. It provides us with all products and equipment we need. However, it has a dangerous dark side which is the pollution associated with important economic sector. Water, air, and soil are victims of such pollution. Tremendous number of efforts from industrial and academic sectors has been evolved to reduce the negative effect of industry on environment by reducing the pollutants emitted to the atmosphere and/or by treating the polluted effluents. One important technique that was employed to accomplish this aim is the adsorption. Adsorption is a physical/chemical process involves the use of a certain material called adsorbent to remove chemical compound called adsorbate from liquid or gaseous phase. Many substances can be used as adsorbents, but the most widely used one is activated carbon. Activated carbon can be defined in many ways. For instance, it can be defined as 
a dense as well as a porous solid that has a very large specific surface area in the form of pores that can accommodate huge amounts of different substances to be adsorbed inside these pores [1]. Activated carbon is manufactured from carbonaceous material (precursors) by carbonization at different conditions.

The most used carbonaceous materials for production of activated carbon are agricultural wastes. Examples of these agricultural wastes include coconut shells [2], palm-kernel shells [3-5], wood chips [3], saw dust [3, 6-8], corn cobs [3], seeds [9-11], barely straw [12], walnut shells [13], Borassus bark [14], and fruit shells [15].

The production of activated carbon involves the usage of one of two processes namely; physical activation and chemical activation [16-17]. In physical activation the carbonaceous material is treated with gases at high temperature. The raw material is pyrolized at $600-900^{\circ} \mathrm{C}$ in absence of air followed, in some instances, by exposure to oxidizing agent (carbon dioxide, oxygen, or steam) at a temperature higher than $250^{\circ} \mathrm{C}$ for activation of the produced carbonaceous material. In chemical activation, the carbonaceous material is mixed with a chemical substance that works as an activator (potassium hydroxide, sodium hydroxide, zinc chloride, sulfuric acid, and phosphoric acid). The mixture is then carbonized at high temperature $\left(400-900{ }^{\circ} \mathrm{C}\right)$ to form the activated carbon which is then washed to remove the chemical activator. Temperature of carbonization [18-20], type of activator and its concentration [21], carbonization time [22], and raw material used for production [23] play important role in determining the properties of the produced activated carbon and its adsorption capacities for different pollutants.
Activated carbon can be used in many applications. It can be used in water treatment [24], industrial wastewater treatment $[4,15]$, domestic wastewater treatment [25], gas purification [26-27], and metal extraction [24]. Activated carbon has also an important medical application since it can be used to treat poisoning and over dose following oral ingestion [28].

The aim of this research paper is to produce a cheap adsorbent that is produced from locally cheap available raw material. Production of such cheap material will encourage industrial facilities to treat their wastewater.

In this research paper dates stones (dates pits) was used as a precursor for production of activated carbon. Different chemical substances (zinc chloride, sulfuric acid, and phosphoric acid) were used as activators. The carbonization was performed in a muffle furnace in inert atmosphere (using nitrogen gas) at two temperatures (400 and $500{ }^{\circ} \mathrm{C}$ ). The carbonization time was one hour and two hours. The different batches of activated carbon produced were tested for methylene blue removal. Samples of the prepared activated carbon were characterized using Fourier Transform Infra Red Spectroscopic technique (FTIR) and Electron Scanning Microscopy. All the samples were tested to investigate their adsorptivity towards methylene blue and this adsorptivity was compared to commercial activated carbon.

\section{MATERIALS AND METHODS}

In this research paper dates stones (dates pits) was used as a precursor for production of activated carbon. Different chemical substances (zinc chloride, sulfuric acid, and phosphoric acid) were used as activators. The carbonization was performed in a muffle furnace in inert atmosphere (using nitrogen gas) at two temperatures (400 and 500 0C). 
The carbonization time was one hour and two hours. The different batches of activated carbon produced were tested for methylene blue removal. Samples of the prepared activated carbon were characterized using Fourier Transform Infra Red Spectroscopic technique (FTIR) and Electron Scanning Microscopy. All the samples were tested to investigate their adsorptivity towards methylene blue and this adsorptivity was compared to commercial activated carbon (Fluka, Switzerland).

\subsection{METHYLENE BLUE}

Stock solution of MB (obtained from Mallinckrodt, USA) was prepared by dissolving $2 \mathrm{~g}$ of the solid $\mathrm{MB}$ in 1liter of distilled water. Working solution was prepared by dilution of stock solution to 100 $\mathrm{mg} / \mathrm{l}$. Calibration curve of $\mathrm{MB}$ was constructed by preparing solutions of different concentrations from working solution of $\mathrm{MB}$ then the absorbance of $\mathrm{MB}$ was determined using a UV/V spectrophotometer (Varian Cary 50, Australia) at $665 \mathrm{~nm}$.

\subsection{PRETREATMENT OF RAW MATERIALS}

The dates stones (DS) were washed four times; the first time using liquid detergent with good rubbing of the stone to remove all foreign materials, followed by washing three times with tap water, filtered out and then soaked in distilled water for ten minutes and filtered out. The DS were placed in the drying oven at a temperature of $105^{\circ} \mathrm{C}$ overnight. The dried stones were crushed using kitchen grinder and sieved with mechanical sieve. The fractions were dried out in drying oven at $105{ }^{\circ} \mathrm{C}$ (overnight).

\subsection{PREPARATION OF ACTIVATED CARBON}

Different samples of activated carbon were produced by changing the conditions of preparation. The conditions to be adjusted were according to Table 1:

TABLE 1: ACTIVATED CARBON MANUFACTURING CONDITIONS

\begin{tabular}{|l|l|l|l|}
\hline Sample\# & Temperature & $\begin{array}{c}\text { Time of } \\
\text { pyrolysis }\end{array}$ & $\begin{array}{c}\text { Ratio of } \\
\text { activator: stones }\end{array}$ \\
\hline 1 & 400 & $1 \mathrm{hr}$ & $1: 1$ \\
\hline 2 & 400 & $2 \mathrm{hr}$ & $1: 1$ \\
\hline 3 & 500 & $1 \mathrm{hr}$ & $1: 1$ \\
\hline 4 & 500 & $2 \mathrm{hr}$ & $1: 1$ \\
\hline
\end{tabular}

Three activators were used: phosphoric acid, zinc chloride and sulfuric acid. The above conditions were repeated for each activator. This procedure was applied to two particle sizes of the date stones; $<200 \mu \mathrm{m}$ and $200-$ $355 \mu \mathrm{m}$. The mixtures of the dates stone and the activators were left overnight, and then oven-dried at $105^{\circ} \mathrm{C}$ for 24 hours.

\subsection{CARBONIZATION (PYROLYSIS):}

The activated stones were placed in crucibles, and placed inside the muffle furnace. Nitrogen gas was allowed inside the muffle furnace to provide the inert atmosphere and then the furnace is turned on to reach the required temperature. Counting the heating time started when reaching the required temperature. Samples of activated carbon were cooled down to room temperature inside desiccators.

\subsection{WASHING, DRYING AND GRINDING}

The carbonized sample were washed several times with distilled water followed by neutralization with $0.1 \mathrm{~N}$ of $\mathrm{NaOH}$ or $0.1 \mathrm{~N}$ of $\mathrm{H}_{2} \mathrm{SO}_{4}$ to remove the activator. The washing process continued until the $\mathrm{pH}$ of the washing water reached around 7 . The activated carbon was oven-dried at $105^{\circ} \mathrm{C}$, cooled in desiccators, ground and sieved to different fractions and stored in sealed plastic bottles. 


\subsection{REMOVAL EFFICIENCY OF THE DIFFERENT SAMPLES}

Batch mode studies were conducted using accurately about $0.1500 \mathrm{~g}$ activated carbon having a particle size $<200 \mu \mathrm{m}$ of each of the prepared adsorbents. Each adsorbent was added to $75 \mathrm{ml}$ aqueous solution of $\mathrm{MB}$ of a concentration of $100 \mathrm{ppm}$, initial $\mathrm{pH}$ of 5.94 and stirred at room temperature for 3.5 hours using magnetic stirrers. At the end of the stirring, the adsorbent was separated by centrifugation at $250 \mathrm{rpm}$ for 5 minutes. The supernatants were spectrophotometrically analyzed for the residual (unadsorbed) MB. The methylene blue uptake $(\mathrm{q})$ is given by: $\mathrm{q}(\mathrm{mg} / \mathrm{g})=(($ initial concentration - final concentration $) * 0.075) /$ mass of adsorbent

\section{FTIR AND SCANNING MICROSCOPY}

The FT-IR spectra of various samples were recorded on Infra red Spectrophotometer Varian, USA, FT IR 800 Scimitar Series. The spectrum of date stone and prepared activated carbon as well as the commercial charcoal was recorded in the range 4000 to $400 \mathrm{~cm}^{-1}$ as $\mathrm{KBr}$ pellets. Pressed $\mathrm{KBr}$ pellets were prepared by grinding $200 \mathrm{mg}$ of carbon samples with $0.5 \mathrm{~g}$ of $\mathrm{KBr}$.

The surface morphology of the date stones, activated carbon samples and commercial charcoal was examined using SEM (JEOLJSM 5300) at different magnification.

\section{RESULTS AND DISCUSSION}

\section{INFRARED (IR) SPECTRAL ANALYSIS}

IR analysis was done to predict the functional groups of the dates stones and for the prepared activated carbon samples for the adsorption process. The surface of carbon materials is, in general, rich in a variety of surface functional groups among which the C-O type groups are predominant [29].

A brief summary assignment of specific functional groups and their frequencies of vibration to the observed FT-IR bands of the date stone and activated carbon are shown in Fig. 1 and 2 respectively.

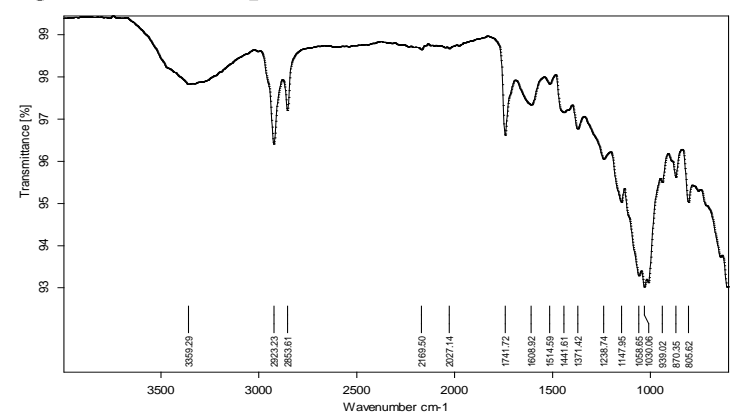

Fig. 1. FT - IR Spectra of the date stone

TABLE 2: SIGNIFICANT FT - IR BANDS OF THE DATE STONE

\begin{tabular}{|l|l|}
\hline $\begin{array}{c}\text { Band position v, } \\
\mathbf{c m}^{-1}\end{array}$ & \multicolumn{1}{c|}{ Assignment } \\
\hline 3359 & $\begin{array}{l}\text { O-H stretching vibration of surface } \\
\text { hydroxyl groups and adsorbed water. }\end{array}$ \\
\hline $2925-2850$ & $\begin{array}{l}\text { Aliphatic, asymmetric } \mathrm{C}-\mathrm{H} \\
\text { stretching vibration }\end{array}$ \\
\hline 1610 & $\mathrm{C}=\mathrm{O}$ (carbonyl) stretching vibration \\
\hline 1740 & $\mathrm{C}=\mathrm{O}$ (carboxyl) stretching vibration \\
\hline $1514-1440$ & $\begin{array}{l}\text { In plane bending vibration of C-H } \\
\text { of methylene group }\end{array}$ \\
\hline 1370 & $\begin{array}{l}\text { In plane bending vibration of C-H } \\
\text { in methyl group }\end{array}$ \\
\hline $1000-1150$ & $\begin{array}{l}\text { C-O stretching in phenols, alcohols, } \\
\text { acids, ethers and esters }\end{array}$ \\
\hline
\end{tabular}

TABLE 3: SIGNIFICANT FT - IR BANDS OF THE COMMERCIAL CHARCOAL

\begin{tabular}{|l|l|}
\hline $\begin{array}{c}\text { Band position } \mathbf{v} \\
\mathbf{c m}^{-1}\end{array}$ & \multicolumn{1}{|c|}{ Assignment } \\
\hline $3100-3500$ & O-H and N-H stretching vibration \\
\hline $3000-3100$ & $\begin{array}{l}\text { Aromatic, asymmetric C-H } \\
\text { stretching vibration }\end{array}$ \\
\hline $2850-3000$ & $\begin{array}{l}\text { Aliphatic, asymmetric C-H } \\
\text { stretching vibration }\end{array}$ \\
\hline $2300-2400$ & $\mathrm{C} \equiv \mathrm{C}$ or C $\equiv \mathrm{N}$ stretching vibration \\
\hline $1640-1750$ & $\begin{array}{l}\mathrm{C}=\mathrm{O} \text { and C-O stretching vibration } \\
\text { attributed to phenolic ester, } \\
\text { carboxylic acid and conjugated } \\
\text { ketonic structures }\end{array}$ \\
\hline $1550-1580$ & $\begin{array}{l}\text { In plane bending vibration of C-H of } \\
\text { methylene group }\end{array}$ \\
\hline $1370-1400$ & $\begin{array}{l}\text { In plane bending vibration of C-H in } \\
\text { methyl group }\end{array}$ \\
\hline $1000-1150$ & $\begin{array}{l}\text { C-O stretching in phenols, alcohols, } \\
\text { acids, ethers and esters }\end{array}$ \\
\hline
\end{tabular}

The infrared spectral data of the date stone show bands at ca $3360 \& 2925-2850 \mathrm{~cm}^{-1}$ region due to $v(\mathrm{O}-\mathrm{H})$ and aliphatic $v(\mathrm{C}-\mathrm{H})$ groups respectively. The spectrum also show 
bands at ca. 1610, $1740 \mathrm{~cm}^{-1}$ due to the $v(\mathrm{C}=\mathrm{O})$ in ketons or carbonyl groups. By comparing the IR spectra of date stones with the IR of commercial charcoal we find that the spectrum of charcoal show an additional bands at ca. 3050-3100 $\mathrm{cm}^{-1}, 2300-2400$ $\mathrm{cm}^{-1}$ due to aromatic C-H stretching vibration and ketone group respectively. On the other hand, the IR spectrum of the three prepared activated carbon samples, using sulfuric acid, zinc chloride and phosphoric acid as activators is similar and the intensity of the peaks were either minimized or shifted slightly compared with the spectrum of the date stone. This can be attributed to the chemisorption process that has taken place due to the presence of all the function groups in the date stone. The IR spectrum of the activated carbon prepared using sulfuric acid, zinc chloride and phosphoric acid respectively is shown in Fig.2. These results are in agreement with the surface chemistries of other activated carbon products from different sources as well as with the spectrum of the commercial charcoal [3032].

\section{SCANNING ELECTRON MICROSCOPE (SEM)}

The pore structure of the activated carbons can be clearly seen from the SEM photographs (shown in Figures 3, 4 and 5). The availability of pores and internal surface is necessary for an effective adsorbent. It is evident that the surface morphology of the prepared activated carbons was different before and after adsorption.

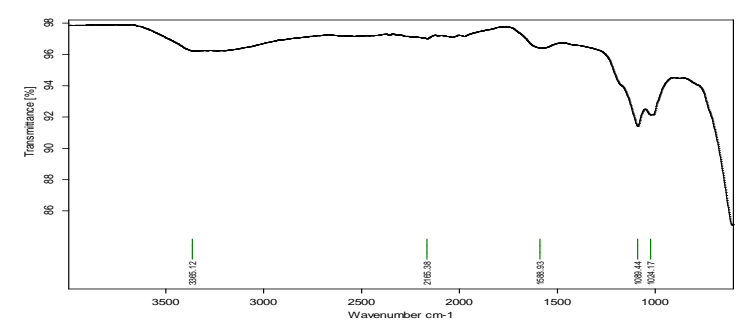

a) Using $\mathrm{H} 2 \mathrm{SO} 4$

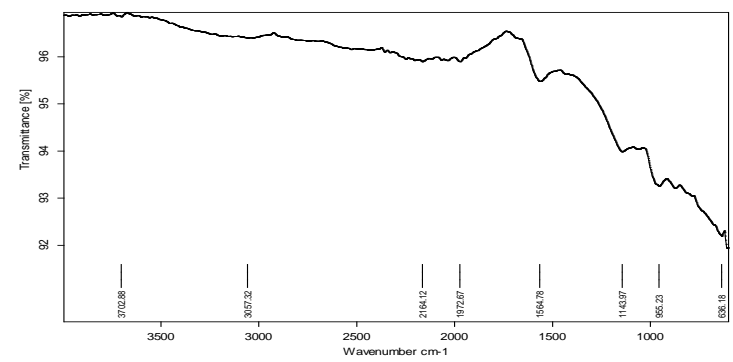

b) Using $\mathrm{ZnCl} 2$

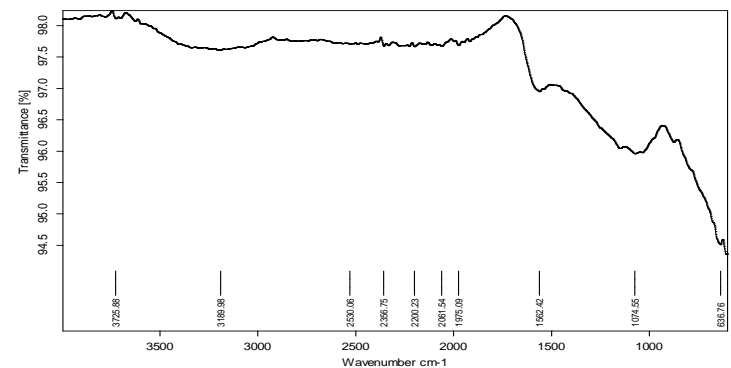

c) Using $\mathrm{H} 3 \mathrm{PO} 4$

Fig.2. FT - IR Spectra of the prepared activated carbon


Fig.3. Scanning electron micrograph of dates stones 


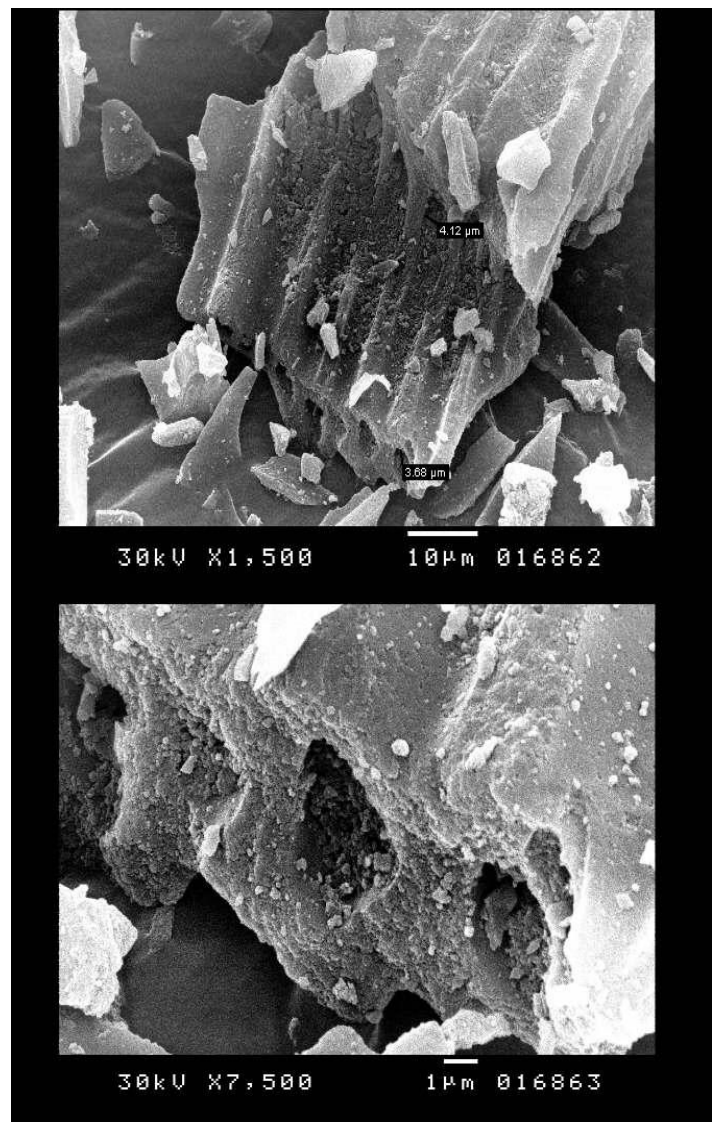

Fig.4. Scanning electron micrograph for commercial charcoal

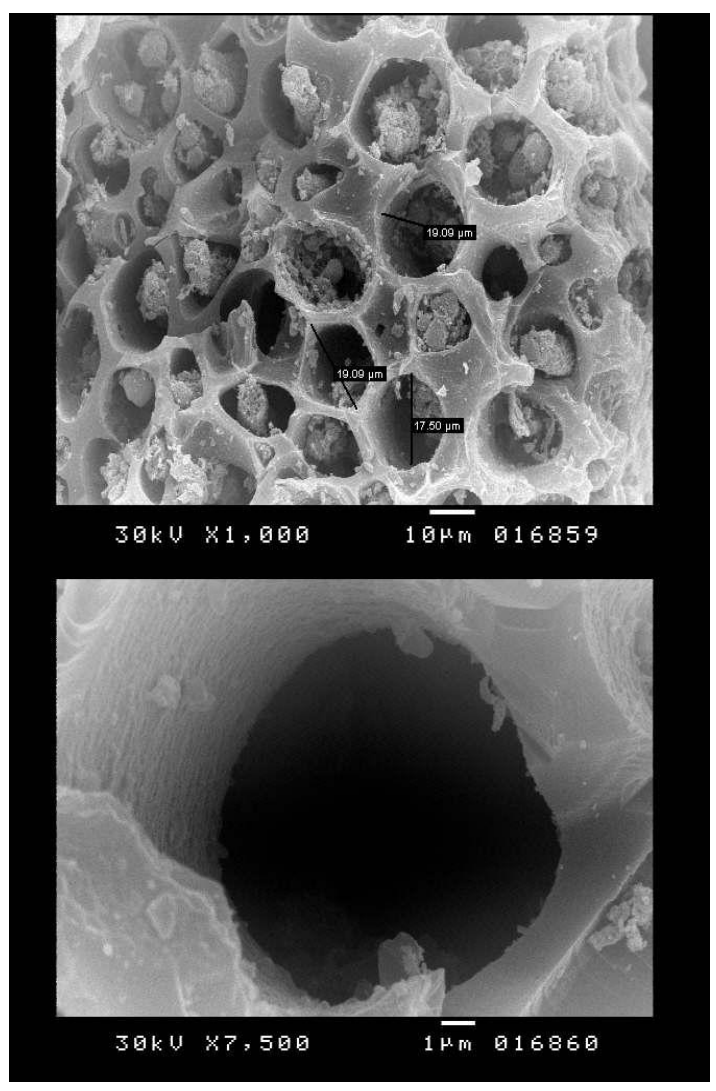

a) Using $\mathrm{H} 3 \mathrm{PO} 4$

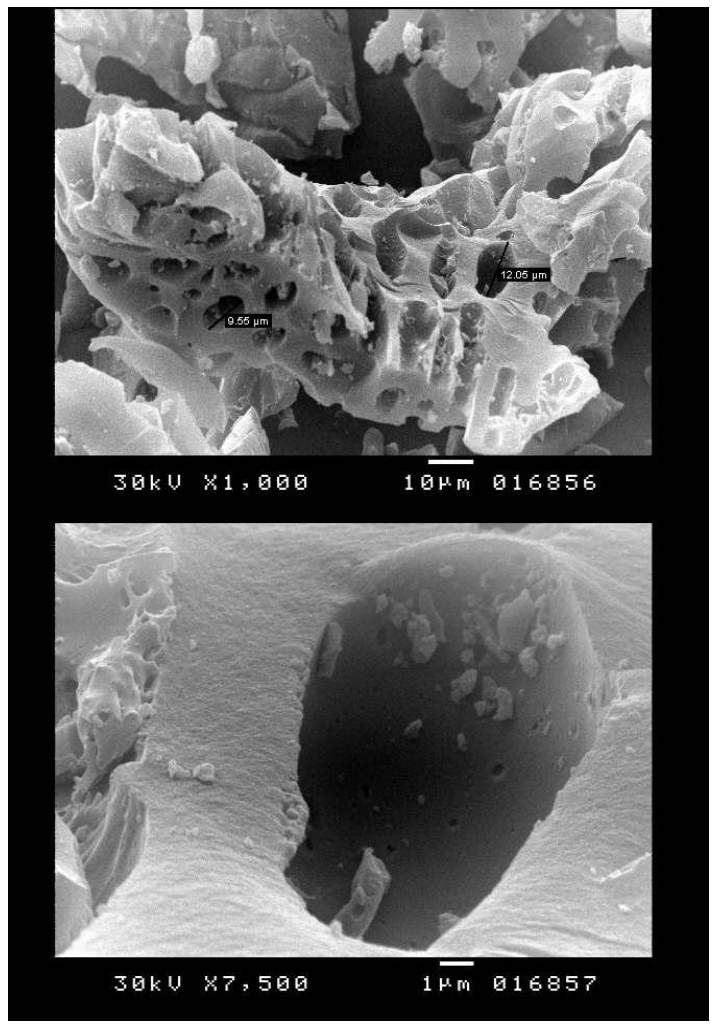

b) Using $\mathrm{ZnCl} 2$

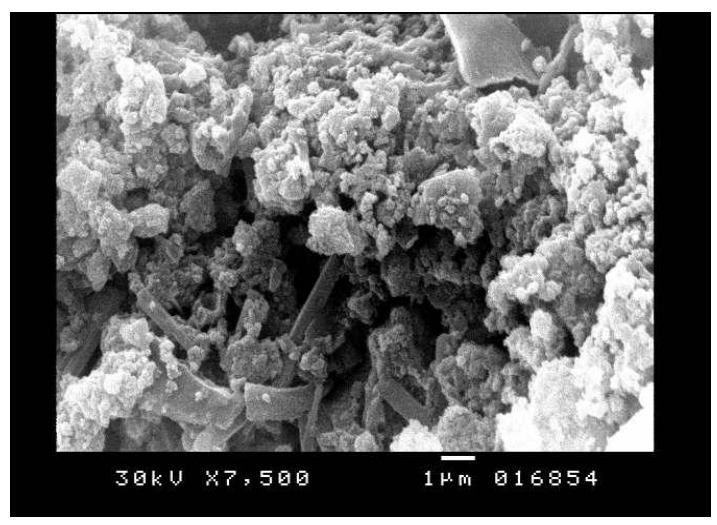

c) Using $\mathrm{H} 2 \mathrm{SO} 4$

Fig.5. Scanning electron micrograph of activated carbons samples

From the figures, it is clear that the chemical activation resulted in a porous structure. According to the International Union of Pure and Applied Chemistry [33] pores on activated carbons can be classified as micropores having an average diameter $(\mathrm{dp})$ less than $2 \mathrm{~nm}$, mesopores $(2<\mathrm{dp}<50 \mathrm{~nm}$ ), and micropores $(\mathrm{dp}>50 \mathrm{~nm})$. All the prepared activated carbons have micropores. This may explain the high adsorption capacities of these prepared adsorbents. 
It can be observed from these figures that in case of using $\mathrm{H} 3 \mathrm{PO} 4$ and $\mathrm{ZnCl} 2$ as activators the pores structure seemed to be of similar shape and size and evenly distributed throughout the particle. On the other hand, in case of activated carbon prepared using $\mathrm{H} 2 \mathrm{SO} 4$, pores are irregular and of different shapes and sizes. A comparison between physical properties of both prepared and commercial activated carbons is illustrated by Table 4.

TABle 4: PHYSICAL PROPERTIES OF PREPARED AND COMMERCIAL CARBONS.

\begin{tabular}{|c|c|c|c|c|}
\hline & $\begin{array}{c}\mathrm{pH}(5 \% \text { in } \\
\text { water) }\end{array}$ & $\begin{array}{c}\text { Loss on } \\
\text { drying, } \\
110^{\circ} \mathrm{C}\end{array}$ & $\begin{array}{c}\text { Ash } \\
\text { content, } \\
600^{\circ} \mathrm{C}\end{array}$ & $\begin{array}{c}\text { Particle } \\
\text { size, } \mu \mathrm{m}\end{array}$ \\
\hline $\begin{array}{c}\text { Commercial } \\
\mathrm{AC}\end{array}$ & $4-7$ & $<10 \%$ & $<1 \%$ & $<200$ \\
\hline $\begin{array}{c}\text { Prepared } \\
\text { AC }\end{array}$ & 2.97 & $1.3 \%$ & $3.5 \%$ & $<200$ \\
\hline
\end{tabular}

\section{REMOVAL EFFICIENCY OF ADSORBENTS}

Figure 6 depicts the methylene blue uptake by different prepared activated carbons. It is clear from the figure that all the prepared activated carbons have considerably high removal efficiency of methylene blue from aqueous solutions.

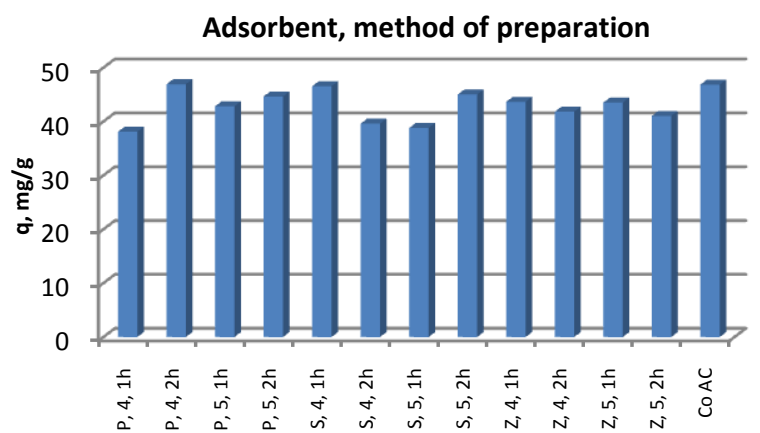

Fig.6. Adsorption of methylene blue by different prepared activated carbons compared to commercial carbon

Legend:

P: phosphoric acid as activator

S: sulfuric acid as activator

$\mathrm{Z}$ : zinc chloride as activator

1h, 2h: Number of carbonization hours

4, 5: carbonization temperature $\left(400{ }^{\circ} \mathrm{C}\right.$ and $\left.500{ }^{\circ} \mathrm{C}\right)$

Co AC: commercial activated carbon
The highest uptake was that for the activated carbon prepared using phosphoric acid as an activator at temperature of $400 \mathrm{oC}$ and 2 hours of activation. The uptake value of this carbon is $46.93 \mathrm{mg} / \mathrm{g}$. This value is higher than that of the tested commercial activated carbon. The difference between the two types having the highest and lowest uptake is only 19\%. The adsorption capacity to this prepared activated carbons towards methylene blue, as illustrated by Table 5, is comparable to other activated carbons prepared by other researchers.

TABLE 5: ADSORPTION CAPACITIES OF METHYLENE BLUE BY SOME ACTIVATED CARBONS

\begin{tabular}{|l|c|c|}
\hline \multicolumn{1}{|c|}{ Precursor for activated carbon } & qe, $\mathbf{~ m g} / \mathbf{g}$ & Reference \\
\hline Periwinkle shells & 500 & 30 \\
\hline Acacia auriculiformis scrap wood & 250 & 34 \\
\hline Wood apple outer shell & 35.1 & 35 \\
\hline Rice husk & 9.73 & 36 \\
\hline Palm oil fiber & 25.06 & 37 \\
\hline Pacan shells & 410 & 38 \\
\hline $\begin{array}{l}\text { Delonix regia pods (Flame tree } \\
\text { pods) }\end{array}$ & 25.1 & 39 \\
\hline Coir pith & 5.87 & 40 \\
\hline
\end{tabular}

\section{CONCLUSION}

In general all the prepared carbons have high efficiency for the adsorption of methylene blue from aqueous solutions. Their adsorption capacities are comparable to that of the tested commercial activated carbon. The surface morphology of the prepared samples indicated micro porous structure. Except for the samples prepared using sulfuric acid, the pores seem to be similar in shape and size and homogeneously distributed throughout the particles. All the prepared activated carbons have different functional groups on the surface, e.g. $\mathrm{OH}, \mathrm{C}=\mathrm{O}, \mathrm{C}-\mathrm{O}$, 
and $\mathrm{C}-\mathrm{H}$, with $\mathrm{C}-\mathrm{O}$ to be the predominating ones.

\section{REFERENCES}

[1] Husseien M., Amer, A.A. El-Maghraby A., and Taha, N. A., Utilization Of Barley Straw As A Source Of A Activated Carbon For Removal Of Methylene Blue From Aqueous Solution, Journal of Applied Sciences Research, Vol.3(11) , 2007, pp 1352-1358.

[2] Laine J., Simoni, S. , and Calles, R., Preparation Of Activated Carbon From Coconut Shell In A Small Scale Cocurrent Flow Rotary Kiln. Chemical Engineering Communications, Vol.99 (1) , 1991, pp 15 - 23.

[3] Lartey R.B. and Acquah, F. , Development National Capability For Manufacture Of Activated Carbon From Agricultural Wastes. The Ghana Engineer, Vol.19(1), 1999, pp 1-2.

[4] Yasin Y., Hussein, M.Z. , and Ahmed, F.H. , Adsorption Of Methylene Blue Onto Treated Activated Carbon. The Malaysian journal of analytical sciences, Vol.11 (11), 2007, pp 400406.

[5] Sai, S., Ahmed, M.J., and Krishnaiah, K. , Production Of Activated Carbon From Coconut Shell Char In A Fluidized Bed Reactor, Ind. Eng. Chem. Res., Vol.36 (9), 1997, pp 3625-3630.

[6] Abechi S.E., Gimba, C.E. , Uziaru A., and Ndukwe, I.G. , Comarative studies of adsorption of methylene blue (MB) by sawdust and walnut shells carbon coated with $\mathrm{ZnO}$. Science world journal, Vol.1(1), 2006, pp 33-35.

[7] Prakash Kumara B.G., Shivakamyb, K., Mirandaa, L. R., and Velana, M., Preparation Of Steam Activated Carbon From Rubberwood Sawdust (Hevea Brasiliensis) And Its Adsorption Kinetics, Journal of Hazardous Materials Vol.136 (3) , 2006, pp 922-929.

[8] Lam M., Zakaria, R., Production Of Activated Carbon From Sawdust Using Fluidized Bed Reactor, International Conference On Environment (ICENV 2008), 15-17 Dec., Penang, Malaysia, 2008, pp 1-12.

[9] Omeiza, F. S., Okunola, O.J., Wyasu, G., and Magaji , L., Adsorption Of Heavy Metals Using Activated Carbon Derived From Carica Papaya Seed, Electronic Journal of Environmental, Agricultural and Food Chemistry, 9 (10) , 2010, pp 1567-1571.
[10] Lafi W.K. , Production Of Activated Carbon From Acorns And Olive Seeds. Biomass And Bioenergy, Vol.20 (1) , 2001, pp 57-62.

[11] Santhi T., Manonmani, S., and Smitha, T., Kinetics And Isotherm Studies On Cationic Dyes Onto Annona Squmosa Seed Activated Carbon, International Journal of Engineering Science and Technology, Vol.2 (3) , 2010, pp 287-295.

[12] Chanda R., Watari, T., Inouea, K., Torikaia , T., and Yadaa, M., Evaluation Of Wheat Straw And Barley Straw Carbon For Cr(VI) Adsorption, Separation and Purification Technology, Vol.65 (3) , 2009, pp 331-336.

[13] Martínez M.L. , Torres, M.M. , Guzmán , C.A. , and Maestri, D.M. , Preparation And Characteristics Of Activated Carbon From Olive Stones And Walnut Shells. Industrial Crops and Products, Vol. 23 (1) , 2006, pp 23-28. 


\title{
تصنيع الكربون المنشط من المخلفات الزراعية المتاحة محليا متمثلة فى نوى التمر لاستخدامه فى معالجة مياه الصرف الصناعى الصناجيا متئرة
}

\author{
حسام الطاهر 1، طارق خليل 2 \\ 1 قسم تقنية الهنسة الكيميائية، كلية ينبع الصناعية، ينبع، المملكة العربية السعودية

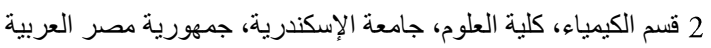

\begin{abstract}
الملخص:
المملكة العربية السعودية لديها العديد من الصناعات الثقيلة والخفيفة. وتنتنج معظم هذه الصناعات مياه عادمة ولذلك بستقبل البحر الأحمر كل يوم آلاف الامتار المكعبة من مياه الصرف الصناعى والتي تحتوي على تركيز ات عالية من الملوثات.

ويتناول هذا البحث تصنيع الكربون المنشط من المخلفات الزراعية المتاحة محليا منمثلة فى نوى التمر لاستخدامه فى معالجة مياه الصرف الصناعى. تتضمن عملية التصنيع استخدام كلوريد الزنك وحامض الفوسفوريك وحامض الكبريتيك كمنشطات كيميائية. وقد تم دراسة تاثير درجة الحرارة وزمن الحرق على فاعلية الكربون المنشط وذلك عن طريق اختبار امتزاز صبغة أزرق الميثيلين (MB). تم ايضا فى هذا البحث دراسة خصائص الكربون المنشط باستخدام الأشعة تحت الحمراء (IR) والمسح الضوئي باستخدام المجر الالكتروني. أثنارت النتائج إلى الكربون المنشط باستخدام حامض الفوسفوريك عند درجة حرارة 400 درجة مئوية لمدة احتر اق ساعة واحدة هو الافضل مقارنة مع النوعين الآخرين.
\end{abstract}

